in the early part of May. We find the festival of ElKhidr and Elias in the middle of the wheat harvest in Lower Egypt ; of this we read :-

"El-Khidr is a mysterious personage, who, according to learned opinion, was a just man, or saint, the Visīr of Zu'l-Karneyn (who was a great conqueror, contemporary with Ibrahìm-Abraham - and identified in other legends with Alexander the Great, St. George, \&c.). El-Khidur, it is believed, still lives, and will live until the Day of Judgment. He is clad in green garments, whence probably the name. He is commonly identified with Elias (Elijah), and this confusion seems due to a confusion or similarity of some of the attributes that tradition assigns to both."

"The 'Festival of El-Khiḍr and of Elias,' falling generally on May 6, marks the two-fold division of the year in the Turkish and Armenian Calendars, into the Rūz Kāsim and the Rūz Khiḍr (of 179-8o and 185-6 days respectively)."

This last paragraph is important, as it points to ancient sun worship, Helios being read for Elias; and 179 days from May 6 bring us to November I. So we find that the modern Turks and Armenians have the old MayNovember year as well as the ancient Egyptians who celebrated it in the Temple of Min at Thebes.

The traces of the Ptah worship are not so obvious. Finally, it may be stated that the second Tanta fair occurs at the spring equinox, so that the pyramid worship can still be traced in the modern Egyptian Calendar. The proof that this was an exotic is established, I think, by the fact that no important agricultural operations occur at this period in Egypt, while in May we have the harvest, in August and November sowing, going on.

\section{THE NEW YEAR'S OFFERINGS.}

In my last article I showed that each year, whenever it began, was, if possible, associated with some fruit of the earth, and that at the winter solstice the chief available vegetable product was the mistletoe.

But about the mistletoe there is this difficulty. Innumerable traditions associate it with the Druids and the oak tree. Undoubtedly the year of the Druids was the solstitial year, so that so far as this goes the association is justified. But as a rule the mistletoe does not grow on oaks. This point has been frequently inquired into, especially by Dr. Henry Ball (Journal of Botany, vol. ii. p. 36I, I864), in relation to the growth of the plant in Herefordshire, and by a writer in the Quarterly Review (vol. cxiv.), who spoke of the mistletoe "deserting the oak" in modern times and stated, "it is now so rarely found on that tree as to have led to the sugges. tion that we must look for the mistletoe of the Druids, not in the Viscum album of our own trees and orchards, but in the Loranthus Europaeus which is frequently found on oaks in the south of Europe."

On this point I consulted two eminent botanical friends, Mr. Murray, of the British Museum, and Prof. Farmer, from whom I have learned that the distribution of $V$. album is in Europe universal except north of Norway and north of Russia ; in India in the temperate Himalayas from Kashmir to Nepaul, altitude 3000 to 7000 feet.

The Viscum aureum, Viscum luteum or Loranthus Europaeus, according to Dixon, ${ }^{1}$ is a near relation of the familiar mistletoe, and in Italy grows on the oak almost exclusively. There are fifty species of Loranthus in the Indian flora, but L. Europaeus does not occur.

In the Viscum aureum we have the "golden bough," the oak-borne Aurum frondens and Ramus aureus of Virgil; and it can easily be imagined that when the Druids reached our shores this would be replaced by the $V$. album growing chiefly on apple trees and not on oaks; indeed, Mr. Davies, in his "Celtic Researches," tells us that 1 Notes and Qurries, Ser. iv. vol. ii. p. xrs. the apple was the next sacred tree to the oak, and that apple orchards were planted in the vicinity of the sacred groves. The transplanting of the mistletoe from the apple to the oak tree before the mystic ceremonies began was not beyond the resources of priestcraft.

It must not be forgotten that these ceremonies took place at both solstices--once in June, when the oak was in full leaf, and again in December, when the parasitic plant was better visible in the light of the young moon. Mr. Fraser, in his "Golden Bough" (iii. p. 328), points out that at the summer solstice not only was mistletoe gathered, but many other "magic plants whose evan. escent virtues can be secured at this mystic season alone."

It is the ripening of the berries at the winter solstice which secured for the mistletoe the paramount importance the ceremonials connected with it possessed at that time, when the rest of the vegetable world was dormant. NORMAN LOCKYER.

\section{THE RECENT VOLCANIC ERUPTIONS IN} THE WEST INDIES.

IN continuation of the articles which have already appeared in NATURE upon the recent volcanic disaster in the West Indies, we are able to give this week some further information upon the character and consequences of the eruptions. Prof. Milne traces the development of the disturbances and uses his intimate knowledge of volcanic and seismic effects to show how they may be interpreted. In addition, we give two separate notes upon the ash ejected during the eruptions, and seismographic records in France on May 6. The nature of the dust ejected from the Soufrière will soon be satisfactorily determined, for last week's West Indian mail brought to this country numbers of packets of the volcanic ash which fell at Barbados, Ioo miles to windward, during the night of May 7-8. The Imperial Department of Agriculture has despatched specimens to the Natural History Museum, the Geological Society, Prof. Judd, \&c.

Arrangements have been made for the small scientific expedition referred to in last week's NATURE, and the members are to sail as we go to press with this number. The expedition consists of Dr. Tempest Anderson, Dr. Flett, and another member of the staff of the Geological Survey. The Colonial Office has promised to assist the Royal Society in defraying the expenses of this expedition.

For convenience, we bring together in diary form the reports of volcanic and other possibly related disturbances which have occurred during the past few days. This record of events is in continuation of those already abridged from dispatches published in the Times, Daily Mail, Daily Graphic and other papers :-

May i8, Autun (France).-Uneasiness is beginning to be felt in regard to the volcano of St. Pierre-de-Varennes, between Couches-les-Mines and Le Creusot, which has always been considered extinct. Low rumblings have been heard, accompanied by tremblings of the earth, and at II. 30 p.m. similar noises of more than usual loudness caused considerable alarm among the inhabitants of the district.

May I8, St. Vincent.-An eruption of the Soufrière occurred between about 8.30 p.m. and midnight, accompanied by thundering noises and incessant electrical discharges.

May 19.- There was a great eruption of Mont Pelée. The volume of lava emitted surpassed that of May 8. It overflowed Grande Rivière and destroyed the buildings and cultivation which were previously untouched.

May 20, Pointe dे Pitre.-Mont Pelée ejected thick black cloud and hot mud and stones, covering the greater part of Martinique. A heavy pall hung over Fort de France, followed by flashes of light.

May 21, Fort de France.-A further eruption of Mont Pelée occurred.

May 22, Victoria (B.C.).-An explosion occurred in the Crow's Nest coal mines at Fernie, in the Kootenay district.

No. I 7OO, vOL. 66] 
May 22, P'ointe it Pitre.-From the new crater on the north side of Mont Pelce the lava is flowing in a broad stream into the sea.

May 24, Fort de France.-Mont Pelée emitted a torrent of lava and mud, which rushed down the northern slope and swept away what remained of the town of Basse Puinte. New fissures also opened in the side of the mountain.

May 24, St. Vincent. - Rumblings are heard and vapour is still issuing from different points on the Soufriere, and lava is still flowing.

May 24, Hamburg. -A fall of so-called "blood rain" occurred in Hamburg and district. It was found that the phenomenon was due to the presence of numerous insects (Carabus cocinella), and it is suggested that they were driven with volcanic dust from Martinique.

May 25, Fort de Franic.-Mont Pelíe is fairly quiet, although there have been eruptions of ashes which covered the extreme north of the island. The new crater is active.

May 25, Genera. - (irey snow fell in the canton of Lucerne. The heaviest fall was at langentbal. When it melted, a substance resembling ashes covered the grass.

May 26, Vienna. - At noon to.day the seismological apparatus at the observatory of Laibach, Carniola, recorded strong earth. quake shocks within a distance of 473 miles.

May 27, Fort de firanie - A fresh and very violent eruption has taken place. The crater has projected a heavy rain of ashes and gravel over the north of the island. At the same time thick clouds charged with electricity floated in the air.

The fears that existed amongst those who escaped the disasters which took place between May 7 and ro that volcanic wrath was not expended have been fully realised. Devastation has succeeded devastation, fertile slopes have been doubly buried, new craters have been opened and molten rock yet flows. On Thursday, May 8 , at about 11.50 a.m. in our time, Mont Pelée did its worst. La Soufrière commenced earlier, and fought the heavens and all within its reach for several days. Next came a period of comparative tranquillity, Pelée for twelve days and Ia Soufrière for seven, but the hopes that this created were destined to be rudely shattered by terrific explosions and fresh bombardments. Surely we may now expect, although spasmodic ejections of vapours, ash and lava will yet occur, that these Titans must, by a process of natural exhaustion, sink back to their original quiescent state. But what about the nerve-shaken survivors who yet feel tremblings of the ground and yet breathe fumes wafted downwards from the peaks which dominate their homes?

During the preliminaries which ushered in the great explosion, when the air was filled with noxious exhalations and soft white ash carpeted streets as if the doomed who remained within their houses were to pass away without hearing the hurrying footsteps of those who rushed aimlessly along in their endeavours to escape, pater nosters were heard from thousands on their knees. Both men and women lost their reason, a mental paralysis was far-reaching, while the sincerest prayers that were ever offered were accompanied by hysteria.

Many sought refuge in the churches, where sacraments werc exposed and services were held. Here, with eyes beyond tears, multitudes with terror graven on their faces confessed and prayed, listened to the exhortations of their pastors and the thunderings of the mountain, awaiting their end. During this reign of terror, which lasted for five long days and nights, no doubt many succumbed.

Then came the final crash, and with a blast of poisonous, suffocating gas, a whirlwind of flame, and beneath a rain of hot ash and blocks of rock, a fair township and its surrounding hamlets which had nestled on Pelée's western strand were seen no more. Only one, we are told, escaped the deadly gas and fire. He was a negro charged with NO. I 700, voL. 66] murder, shut up in a subterranean prison. The destruction was even more complete and terrible than that which was accomplished by brimstone and fire in the days of Lot.

When the more violent thunderings ceased, let us consider what next happened amongst the survivors around the desert of desolation. The majority rose from their knees, to be terrified by every puff of steam they saw and to rush from their houses at the slightest tremor of the ground. For years to come, not only will the eruptions in Martinique and St. Vincent form a subject of conversation, but the month of May and the year IgOz will, like the twenty-seventh year of Uzziah, when a mountain near Jerusalem was moved $; 00$ paces and the temple rent in twain, mark a period from which to date events. No doubt survivors are yet pouring into each other's ears fresh tales of horror, whilst grumblings in the distant hills result in delirium and prayers. Many will no doubt sing hymns and devote themselves to religious exercise, and perform acts of penance. Noorthouck, in his "History of London," writing about the effects of earthquakes and referring to that which occurred in the West Indies in $169 \mathrm{r}$, tells us that "such intermittent fits of reformation excited by fear resemble death-bed repentances too much to merit any encomium."

Although Noorthouck's view is sustained by the action of those who had courage to back cupidity by returning to the still smoking débris which represented St. Pierre and rob from corpses, yet those who write the history of this disaster will no doubt find that the shock which the nervous system of survivors sustained has had some lasting effect. By this time, no doubt, not only in the West Indies, but throughout the world, these cruptions have afforded materials for many sermons and moral dis. courses, and for some time to come a cloud of smoke from the throats of Pelé or the Soufriere will claim a misericordia in response.

After the disaster which overtook Jamaica in 1691 , we understand that a sentence was interpolated in the Litany as used in that island, whilst the special prayers which have been formulated in consequence of volcanic disturbances are numerous throughout the world. In the history of nations we read that these outbursts have resulted in officially ordered prayers, gifts to temples, special services, the repeal of taxes considered to be unjust, and in many other directions have had a more or less permanent effect upon the social, religious and civil lives of many people.

Those who dwell in countries like our own, where displays of volcanic activity are unknown, possibly think themselves beyond the pale of the emotional influences which they exert. When, however, they call to mind the fact that the vulgar of many nations, to use the words of Buffon, have regarded volcanoes as the mouths of hell, their bellowings to be the cries of the damned and the eruptions the effects of the fury and despair of the wretched prisoners, and add to this the fact that through. out all history equally strange ideas have immediately followed on the heels of unusual displays of volcanic and seismic activity, it is difficult to suppose that any nation can exist that has not suffered or been benefited by these mental aberrations. In Japan we have the myth of the buried cat-fish which shakes the empire, and the effect of this poetical idea is met with in the pictures and art of that empire; whilst parallel stories with their parallel effects are found in many other countries. The strange thing is that these emotional creations seem to spread far beyond the limits of the ashes and the tremblings which produced them, to flourish where the imaginative faculty is the strongest. Although we are without volcanoes, we have only to recall names like Pluto, Vulcan and Poseidon and the line in the Decalogue which tells we are not to make any likeness of that which is in the earth beneath to realise that volcanic activities have had 
a marked effect upon our religion, our literature, our pictorial and our glyptic art.

Those who visit the West Indies with the object of extending our knowledge of vulcanology will no doubt collect information bearing on these far-reaching effects, and it is not unlikely that it will be found that the eruptions in the Antilles have done more to stimulate the imaginations of Europeans than those of the negroes who witnessed all that happened.

Another neglected chapter in hypogenic geology to which attention may be directed relates to the effects of volcanic activity on epidemic diseases, a subject which has attracted the attention of many investigators. American and Italian statistics, Dr. Bardswell says,

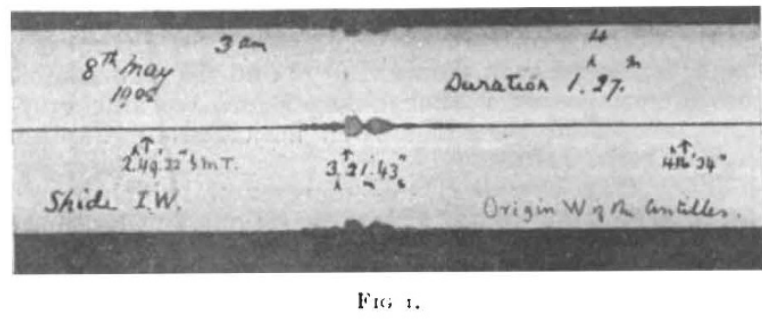

show that there is "an increased death-ratc from malaria, enteric, \&c., with a lessened death-rate from phthisis in areas associated with volcanic activity as compared with non-volcanic regions"-a statement, however, not beyond criticism.

No doubt types of neurosis like nausea, disordered sensation, nervous apprehension, insanity, paralysis of the limbs and other kindred troubles will have a sporadic existence, but it does not seem likely that these will be so marked amongst the negroes as amongst the Europeans.

The destruction of water-pipes or the contamination of water supplies by sewage might result in diseases like cholera and typhoid. Although cases of bron.. other, may be stirred into activity in regions far removed from volcanic centres, to result in diseases which may affect, not only animals, but also plants.

The causes of death in St. Pierre were no doubt manifold. First there was the blast of irritating gas and dust which caused suffocation. In all probability this gas was in the main that of hydrochloric acid derived from the sodium chloride of the sea-water, the infiltration of which is the main cause of all volcanic activity. This gas has been pouring out of Pelée and La Soufrictre in the columns of steam during all stages of their eruptions and by this time, no doubt, it exists as a belt round our world, many of the inhabitants of which are breathing exhalations which had their origin in the West Indies.

Many were killed, particularly at I a Soufriere, by a rain of hot ashes or by lightning, which played in the darkness of the ashy cloud like fiery serpents.

On May S, when Pelće burst an opening on its flanks, a whirlwind of fire or a sheet of flame, followed by redhot ashes, stones and boiling water, swept over St. Pierre and its harbour to seer and scald and fire all that it passed. We have here a phenomenon deserving close attention. If this flame really existed, what was its origin? Mr. F. J. M. Page gave the writer the suggestion that it was the ignition of a "water gas" produced when the water forming the lake in the crater of Mont Pelce was suddenly admitted into the fiery furnace of its interior. The action would be sinilar to that which takes place when a teaspoonful of water is thrown upon a hot fire; dissociation would take place, an explosion would occur, and the resultant gases would be ignited as a flash. That the inhabitants of a city should be overwhelmed by a wall of fire created by the cool waters of the lake in which they bathed seems incredible, but still, this is at present the only explanation we have for this unparalleled occurrence.

About premonitory signs a correspondent of the New York Herald tells us that dumb animals were wiser than man, live stock were uneasy and almost uncontrollable. Cattle lowed in the night, dogs howled, and when driven out showed symptoms of fear. Wild animals disappeared from Mont Pelée. Even snakes crawled away. Birds

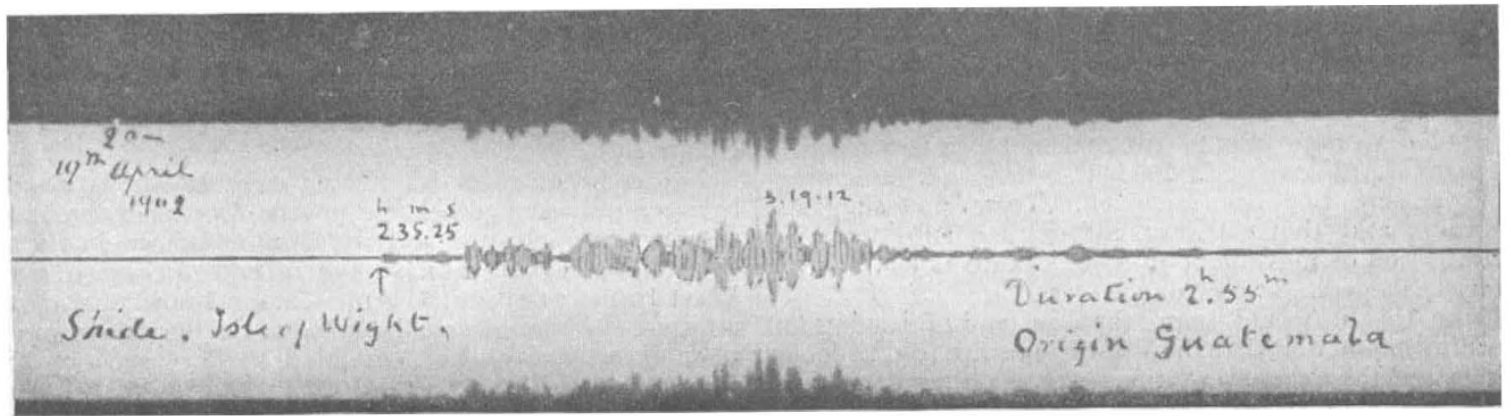

Fig. 2.

chitis have resulted from the inhalation of rolcanic gases, discases arising from these causes are extremely rare.

An ingenious theory, showing the possibility of a re. lationship between volcanic action and the production of epidemic diseases: is one advocated by Dr. W. (.$A$. Robertson. He does not assume that poisonous products issue from volcanic vents to render the atmosphere poisonous, or even that these products appreciably affect its constitution. What, however, he does assume is that these gases and vapours may be dilated to an immense extent to produce an atmosphere suitable to the vital activity of unicellular organisms. According to this view, microparasites, which are always present somewhere or ceased singing and left the mountain, and a great fear seemed to be upon the island.

Signs like these, which usually are only recognised after a catastrophe has taken place, are by no means peculiar to the Antilles. The late Prof. S. Sekiya, of Tokio, kept pheasants to study their behaviour before an earthquake, and I have had many opportunities of confirming his observations, which show that these birds by their screaming feel the preliminary tremors of an earthquake, to which movements human beings are in sensible. This, then, being the case, it does not seem at all unlikely that the creatures living on the slopes of Mont Pelée heard sounds and felt vibrations the occurrence of which was not noticeable by man. Although

No. 1700, vol. 66] 
Cicero, in the "De Divinatione," says that "God has not predicted so much as the divine intelligence of man" and omitted reference to the intelligence of the lower animals, it seems probable that in certain directions the instinct of brutes is not to be overlooked.

The small earthquakes which frequently precede a volcanic eruption are usually referred to as abortive attempts made by internal forces to establish an opening. But should all such earth shakings be regarded in this manner? It seems likely that some of them may be simply intermittent yieldings in the general process of rock folding, which, when it has sufficiently relaxed its hold upon the imprisoned vapours, allows the same to burst forth as an eruption. Whether before the eruption there were unusual escapes of gas from subterranean sources, whether there bad been changes in colour, taste, level or temperature of the water in wells and springs, we have not yet been told.

Neither have we. been told of any prophet who boldly came forth and announced the impending danger; but what we do know is that whilst the Governors of the Windward and Leeward Islands are yet striving to allay the fears of terrified inhabitants, thoughtless Cassandras are predicting tornados, new eruptions, and even the sinking of the islands. As we have said before, tornados always occur in these islands between July and October, and volcanic displays usually sink back into quiescence in an intermittent manner. To call attention to what is inevitable in terms suggesting that even greater catastrophes than have yet been experienced are to be expected, may make sensational paragraphs and cheapen property. It can, however, only excite alarm, create panic, trouble the civil administration and accelerate the depopulation of the islands, and therefore prognostications of this character should at least be discouraged. What grounds there are for supposing that the Antilles may sink beneath the ocean is a mystery. Cinder heaps. which have risen above the ocean as volcanic islands have by the action of the waves been reduced to shoals, but with the Antilles we are dealing with a fold in the crust of our earth which, if the water was removed from its flanks, would stand up like a chain of mountains 18,000 feet in height. Parallel with this is the fold of the Cordilleras, with its peaks 12,000 feet in height, bounded by an ocean more than 14,000 feet in depth.

It seems that it was an adjustment in this latter fold which took place on April 19, when several towns were ruined and more than Iooo people lost their lives, which led to adjustments announced by earthquakes in the parallel Antillean fold. Pelée then smoked, indicating that pressure had been relieved. This relief suggests elevation, and that elevation rather than subsidence is the direction of movement in these islands is testified by a variety of geological evidence.

From this it would seem that, instead of issuing an alarming prediction that the West Indies are to disappear from view, the recent eruptions suggest that they have risen to a greater height, whilst the water on their Caribbean side may. have deepened. Two wrinkles on the face of the world have probably gained in height, whilst the depth of the bounding furrows on their western flanks has probably been increased. As indications of these changes, newspapers state that Richmond in St. Vincent has risen, whilst a French cable ship has found at a certain spot an increase in the depth of water of nearly 500 fathoms.

The public are evidently anxious that volcanic eruptions and seismic disturbances should be preaicted, but as districts where these activities prevail are not transparent and we cannot see what is happening beneath our feet, neither are we able to measure the pressures and strains which may be increasing in such regions, the time when a ball rising on a mast will announce impending subterranean disturbances seems very distant. Still, No. I 700 , vOL. 66$]$ there are directions in which investigations bearing on this point may be pursued. One of these would be to determine whether before a volcanic outburst or after the same there were any unusual changes in level in operation. Lyell remarks that if we reflect upon the dates of the principal oscillations noted near the Bay of Naples, there appears to be a connection between the movements of upheaval and a local development of volcanic heat, whilst periods of depression are concurrent with periods of volcanic quiescence. The part that the horizontal pendulum would play in such an investigation is obvious.

A second line of research would be to determine whether the movements of magnetic needles placed in the vicinity of a volcano show any relationship to its eruptions. We know that many lavas are highly magnetic, and it is not unlikely that physical and chemical changes, together with mechanical displace ments of such materials, would result in changes in magnetic elements in their vicinity ; and that remarkable coincidences between such changes and volcanic eruptions have taken place has been indicated by Captain E. W. Creak, F.R.S.

There may be other lines of research which would throw light upon subterranean operations, but these are two which might be pursued without great difficulty.

\section{On the Sequence of Events.}

From the enormous displacements of ground which have frequently accompanied world-shaking earthquakes, and from the fact that their origins can be traced to districts where we have evidence of secular movements which may be yet in progress, it is not unreasonable to suppose that such earthquakes are announcements that strains have suddenly been relieved in certain orogenic foldings. This relief may be compared to the movement of a key which fires many mines. Not only might volcanic vents beneath which there was excessive pressure burst into activity along the fold, but similar displays might be expected in neighbouring folds. In support of these views attention may be called to the fact that the mountain-making epochs in geological history were periods of intense volcanic activity. From the middle to the end of the eighteenth century, earthquakes and volcanic eruptions were frequent throughout the world. The history of the large earthquakes of Japan shows an approximate coincidence in time between these phenomena and volcanic eruptions, and similar coincidences can be adduced from the registers of other countries.

Evidences of this description suggest a relationship between pronounced seismic efforts in or near a volcanic region and volcanic activity, and when we know the sequence of events which have recently occurred in the West Indies and Central America, our knowledge of the relationship between earthquakes and other subterranean phenomena may be extended. The seismograms reproduced in Figs. I and 2 are of interest in this connection.

On April 19 at about half-past two in our time, the Cordilleras of Central America were suddenly relieved of seismic strain, villages and towns were shattered, earthquake waves passed all over our world and all through the same, whilst in the epifocal area we learn that at one town alone I I0O people lost their lives. Whether this widespread disturbance was quickly followed by adjustments in the neighbouring Antillean ridge we are not certain. All that can be gathered from newspapers is to the effect that about the end of April many small earthquakes took place and Mont Pelée smoked and rumbled. On May 3 this mountain was in eruption and ashes fell upon St. Pierre. Two days later it ejected a stream of mud and commenced its work of serious destruction. The sea receded 300 feet, and the Puerto Plata and the Dominica-Martinique cables were interrupted. On this 
day $\mathrm{La}$ Soufrière, ninety miles to the south, gave evidences that it was disturbed, but it was not until 2 p.m. on May 6 that it can be said to have erupted. At 7 a.m. on May 7 the eruption was violent. At noon three craters opened, lava flowed, ashes were driven to a height of eight miles, to fall upon Kingstown, twelve miles distant, whilst the schooner Ocean Traveller had to fly to escape destruction from the showers of lapilli. A violent explosion took place at I.30 p.m., whilst at 3 p.m. the detonations were terrific. One hour later a dust cloud, which apparently had travelled in the teeth of the trades, reached Barbados. Dust or extremely fine ash was falling at or before 5.30 , and in three days, when the eruption in St. Vincent moderated, a thin layer of this covered Barbados. The weight of this dust layer, which has already been analysed and is expected to improve the texture of the soil, is estimated at two million tons. This is what La Soufrière, assisted by an upper current of air, effected at a distance of 100 miles eastwards from its crater. It may here be noticed that this mountain commenced its violent outbursts, which extended over three days, before the explosion of Mont Pelée, which happened at I I.50 a.m. on May 8, although Mont Pelée was in eruption some days before La Soufrière.

The Dies Irae for St. Vincent was May 7, whilst for Martinique it was on May 8. Other events of considerable significance which happened on May 7 , but about which we have as yet but little information, were, first, the St. Lucia-Martinique, the St. Lucia-St. Vincent, the St. Lucia-Grenada and the Guadeloupe-Martinique cables were interrupted; second, at Io p.m. a very strong earthquake shook St. Vincent; and lastly, in St. Vincent time in the Isle of Wight a seismograph commenced to indicate at roh. $45 \mathrm{~m}$. p.m., the maximum motion being attained at I I.I6 p.m. The character of the seismogram is that of a disturbance which originated at a distance from the Isle of Wight of between $60^{\circ}$ and $70^{\circ}$. From this it is inferred that the time at which this disturbance originated was about I0.33 p.m.

Now St. Vincent is $60^{\circ}$ from Great Britain, but whether the earthquake which took place in that island is identical with that recorded in Britain and represents a suboceanic convulsion which interrupted the cables on that date can only be definitely settled by those who know the hours at which these cables ceased to work.

The suboceanic disturbance which at 6.32 a.m. on December 29, 1897, interrupted the cables off Hayti gave in England a seismogram which was comparatively large. In this case, although the seismogram is small if we for the present assume the disturbance it represents to have originated off St. Vincent, it indicates that the sudden adjustments in the earth's crust accompanying the eruption of La Soufrière were more violent than those which took place around Mont Pelée, from which earthquakes of any magni ude do not seem to have originated. The considerations attending the laying of cables are no doubt numerous, but from the fact that those which have been mentioned for the most part pass along the western side of the Antilles, it cannot be said that they occupy the best position o avoid the effects of submarine convulsions. A comparison of the registers of the interruptions these cables have experienced with those of earthquakes which may have been recorded at many very distant stations would throw great light upon the geological activities in progress beneath the Caribbean Sea.

To turn back to Mont Pelée and La Soufrière, we see that after their paroxysmal efforts, when 2000 lives had been lost in St. Vincent and 40,000 in Martinique, the eruptions at these mountains moderated, but this was only for a time. On May i7 another great eruption took place at La Soufrière, whilst on the 2oth Mont Pelée destroyed everything that had remained No. I 700, voL. 66] standing at St. Pierre, and, as if filled with a desire to destroy more life, showered stones and ashes on Fort de France, thirteen miles distant. The northern ends of two islands have now been destroyed and the eruptions continue, whilst in St. Lucia, which lies at a distance of about twenty miles from each of these scenes of destruction and exactly between them, the boiling sulphur springs and volcanoes remain in their normal conditions.

With the great eruptions of Pelée on May 3, 8, 19 and 20 there appear to have been disturbances of sea level, the water either rising or receding. With that of $\mathrm{La}$ Soufrière on the 17 th, we read that at Château Belair every few hours there were continuous convulsions of the ground, at Kingstown and Georgetown there were sixty shocks in four hours, whilst the village of Wallibou partly sank and that of Richmond rose. All these phenomena, taken in conjunction with the interruption of cables, indicate that the more violent displays of activity were accompanied by adjustments in the neighbouring strata, and it is more likely that such adjustments were the cause rather than the result of the marked phases of activity.

About unusual phenomena which occurred at a distance we have as yet but little information.

On May I I a geyser or boiling lake in Dominica, some 300 feet in length and 200 feet in breadth, disappeared. The next day some boiling springs at Bath, in Janiaica, became extremely hot. On May 13, and for several days previously, Pico de Colima, a volcano I 2,700 feet high, in Mexico, created alarm by belching forth puffs of smoke, whilst at St. Thomas at 4.30 p.m. a slight earthquake was felt. On May I 8 an earthquake was felt throughout California. Up to noon on Sunday, May 25, with the exception of what has here been noted, the instruments in the Isle of Wight have been at rest.

J. Milne.

\section{Volcanic Ash at Barbados.}

Volcanic ash fell very thickly at Barbados in the afternoon of May 7, in consequence of the eruption of the Soufrière on St. Vincent, and caused almost total darkness in the afternoon. On the morning of May 8, we learn from the Barbados Advocate, kindly sent to us by Sir William Thiselton-Dyer, the streets were found to be covered with this grey dust, and it was estimated that about twenty-two tons per acre fell in twelve hours. The ash lay so thick in the streets that traffic was interfered with, and great difficulty was experienced in clearing it from houses and approaches.

There was a fairly strong east wind prevailing during the whole period, and ordinarily speaking, St. Vincent being to the west of Barbados, it would have been considered impossible that the dust could have travelled in this direction nearly a hundred miles against the wind. But whilst the prevailing direction of the wind was from the east, the upper currents of air travelled from the west, and the phenomenon observed in the eruption of 1812 was repeated in the present. The dust was hurled from the volcano into the upper strata of air and borne eastward against the direction of the surface currents.

According to the official statement in the Agricultural Nezes, the quantity of ash that fell varied from three-eighths to half an inch in depth, covering everything with a grey mantle of impal. pable dust. By actual measurement it was ascertained that the weight of ash was at the rate of $17.5^{8}$ tons per acre, probably nearly two million tons being deposited over the whole of Barbados. Prof, d'Albuquerque's preliminary chemical examination led to the conclusion, which was contrary to expectation, that the ash was of no fertilising value, but that it may tend to improve the texture of the surface layers of heavy clay lands. Dr. Longfield Smith's preliminary mineralogical examination disclosed volcanic minerals and volcanic glass, the minerals predominating, and consisting chiefly of silicates of iron and magnesia, also a considerable proportion of quartz and some potash felspar. Under 
the microscope the samples of the dust which fell in 1812 and 1902 differed greatly, the 1812 dust being much finer and con. taining very few mineral crystals, being chiefly composed of fragments of dark brown volcanic glass. During the recent fall it was noticed that the ash at first was rather coarse and of a brownish colour, then it became slightly redder, while the final deposits consisted of a whitish-grey impalpable powder.

From a meteorological standpoint the conveyance of the dust from St. Vincent to Barbados is a subject of great interest, as bearing upon the question of the upper currents. At sea level the trade wind blows almost directly, and freshly, from Barbados to St. Vincent, east to west. The Soufrière became active early in the afternoon of Wednesday, May 7 ; the dust cloud must have been shot up to an elevation of some miles, where it was caught by a west to east counter current of great velocity, for within two hours, 3. I 5 p.m., dust was observed to be descending in Barbados, gradually increasing in volume and becoming heavy soon after sundown, the consequent darkness being intense. There was brilliant lightning and violent crashing thunder. It would appear that on this day the upper current had an east-going velocity of more than fifty miles an hour.

It is worthy of mention that at $1.30 \mathrm{p.m}$. on May 7 there occurred a sudden outburst from one of the oil borings, 900 feet deep, at Turner's Hall, Barbados, dust being thrown up to the height of more than Ioo feet into the air. At 3.45 p.m. there was an unusually high tide at Bridgetown, the highest within memory.

\section{Seismographic Records in France. ${ }^{3}$}

I received, on May 6, a telegram from M. Kilian, professor of geology at the University of Grenoble, announcing that the Kilian-Paulin seismograph had registered in the morning at 3h. 4m. 49s. Paris time a seismic shock from a north east direction. The evening papers and those of the next day announced that this shock had been felt again in the north-west of France and along the south Mediterranean coast of Spain. It is in the district of Murthia that the most violent effects were notified.

Another more precise observation as regards time and direction of the shocks has been recorded at Floirac near Bordeaux, north-west direction, time $3 \mathrm{~h} .5 \mathrm{~m}$. $30 \mathrm{~s}$; ; the passage of the vibrations therefore made themselves felt at Floirac forty-one seconds after those of Grenoble. In supposing them to have a speed of $3 \mathrm{~km}$. a second, the epicentrum must be $123 \mathrm{~km}$. further from Floirac than from Grenoble and also to the south east of Floirac, to the south-west of Grenoble. These theoretical and bypothetical considerations would place it in the Mediterranean, to the east of Murthia, to the south of Minorca. Wherever it is, it seems to me that the earthquake of May 6 affected the subsidence in a Mediterranean oval, which has cut the south coast of Spain, by marking it with volcanic eruptions (Olot, Columbret, Cartagena, Cap de Gâte). It is interesting to remark that it is equally the result of a subsidence in a Mediterranean oval, that of the Lesser Antilles, that two days after, May 8, there was the terrible catastrophe of Saint-Pierre.

\section{NOTES.}

AT the next meeting of the British Association, to be held at Belfast, commencing on September 8 , it has been decided to include in Section A a subsection for seismology. The organising committee of this subsection invite cooperation of seismologists, who, it is hoped, if they are not able to attend will be able to send communications for discussion.

A REUTER telegram from Upsala says that a Swedish expedition for taking meridian measurements will leave Tromsö for Spitsbergen on July 26. It will be under the leadership of Dr. P. Rubin and will include, as astronomer, Dr. von Zeipel, and, as cartographer, Lieutenant Duner. The expedition will have as a centre the seven islands to the north of Spitsbergen, and will return to Tromsö on September Io.

Mr. J. S. BudGeTt, Balfour student of the University of Cambridge, left England last week for Uganda, viâ Mombasa, on

1 Translation of a note by M. Michel Lévy in the Comptes rendus of the Paris Academy of Sciences, May 12.

No. 1700 , vOL. $66 j$ a mission from the Zoological Society of London. He will proceed to the south-east corner of the protectorate, and take up a station on the Semliki River, where he will collect mammals and birds, study the fishes, and endeavour to investigate the habits of the okapi in the forest of Mboga. Mr. Budgett, who has already paid two visits to the Gambia, is a practised collector of fishes and an experienced African traveller.

AT the anniversary meeting of the Royal Agricultural Society, held last week, the Prince of Wales was elected president of the Society for the year following the Carlisle meeting this summer.

THE British Medical Journal announces that a scientific commission, consisting of Dr. G. C. Low, Dr. C. Christy and Dr. Castelani has been sent to Uganda by the Royal Society for the purpose of investigating sleeping sickness. To Dr. Low and Dr. Christy is entrusted the parasitological part of the investigation, while Dr. Castelani is the bacteriologist of the expedition.

We learn from the Victorian Naturalist that after an absence of rather more than twelve months, the greater part of which was spent among the aboriginals of the northern interior of Australia, Prof. Baldwin Spencer, F.R.S., and Mr. F. J. Gillen returned to Melbourne on March I7. They were in excellent health, and were welcomed home by a number of gentlenıen prominent in literary and scientific circles. The explorers have brought back a considerable amount of material, including phonograph and kinematograph records, on which to base an extensive work on the myths, customs, \&c., of the various tribes studied.

The Times states that Mr. W. Bruce, who is to lead the Scottish Antarctic expedition, has received intimation, dated January 4, from Prof, von Drygalski, leader of the German South Polar expedition, announcing the arrival of the Gauss at Kerguelen. The expedition will, therefore, have made the ice at about the same time as the Swedish and British ships. Von Drygalski has penetrated the Antarctic region at the point of the still hypothetical termination island in order to discover the western side of Victoria land and clear up its possible connection with Kemp and Enderby lands. By taking this route he believes he may be ultimately able to sweep westwards by a high southern latitude into the South Atlantic and emerge by way of South Georgia.

A CORRESPONDENT directs our attention to the announcement that a very fine example of the blue Puya is in flower in the Mexican portion of the temperate house at Kew Gardens, where it is now bearing two stout spikes, three feet high, of beautiful peacock-blue flowers. The plant is a very remarkable one and has rarely flowered in this country, though Messrs. $J$. Veitch had one in flower in I868 (Botanical Magazine, t. 5732).

THE International Commission for Scientific Ballooning met in Berlin last week in the Sitzungssaal of the Reichstag. We learn from the Daily Graphic that Prince Frederick Henry presided in the name of the Kaiser. The War Offices of all the great European Powers except France were represented at the conference. The object of the commission is to combine the study of meteorology with aëronautics, and to induce the various Powers to agree upon some common course of action with regard to the study of aëronautic questions. A paper was read by $\mathrm{Mr}$. Patrick Alexander on the steering by Hertzian waves of flying machines carrying instruments for registering the temperature and moisture of the atmosphere at different altitudes. Mr. Alexander claims that his machines can be sent a distance of fifty miles and steered back to the 